\title{
The Connexus of Management by Objectives and Organisational Performance: Evidence from Tuyil Pharmaceutical Limited, Ilorin
}

https://doi.org/10.21272/sec.4(2).90-98.2020

Bolatito Amudat Brimah, ORCID: https://orcid.org/0000-0003-3272-0304

$\mathrm{PhD}$, Head of the Department of Business Administration, Faculty of Management Sciences, Al-Hikmah University, Ilorin, Nigeria

Ayodeji Gbenga Bamidele, ORCID: https://orcid.org/0000-0003-1114-0714

$\mathrm{PhD}$, Course Facilitator, Department of Business \& Entrepreneurship, School of Business and Governance, Kwara State University, Malete

Rukayat Oloruntoyin Rabiu, ORCID: https://orcid.org/0000-0001-9781-039X

M.Sc., Department of Business Administration, Faculty of Management Sciences, Al-Hikmah University, Ilorin, Nigeria

Iliya Senchi John, ORCID: https://orcid.org/0000-0003-2711-0412

Department of Business Administration, Faculty of Management Sciences, Al-Hikmah University, Ilorin, Nigeria

\begin{abstract}
In modern conditions, the competitiveness of enterprises largely depends on the ability of management to ensure the necessary economic efficiency of operational activities, achieving strategic and tactical goals, rational use of labor, financial and material resources, which determines the relevance of research on innovative approaches to management "by goals". The article substantiates that this concept is focused on increasing productivity through clear guidelines for each employee of the organization and increase staff motivation through its participation in setting their own goals. The main purpose of the study is to examine the relationship between the practical use of the method of "goal management" in the company and its organizational effectiveness. The object of the study was selected pharmaceutical company "Tuyil" (Ilorin, Nigeria) and its staff with a representative sample of 242 people. The source of the primary information in this study was the results of a survey of company employees. The analysis of the survey results was performed using the methods of descriptive statistics and analysis of variance (ANOVA). It is empirically confirmed and theoretically proved that the practical application of the principles of "goal management" is closely correlated with the efficiency of the company. The results of the study provide recommendations for improving the system of "goal management" in the company, namely: the creation of favorable internal relations among employees, which would guarantee their commitment and loyalty to the organizational goals and objectives of the company; Establishing feedback, which involves constant monitoring of the achievement of goals and determining their progress in the implementation of specific tasks, as well as bringing to the management of those unplanned problems that arise in the process of achieving goals.
\end{abstract}

Keywords: goal commitment, performance feedback, task complexity, organisation, Nigeria.

JEL Classifications: D23, L21, M10.

This work is licensed under a Creative Commons Attribution 4.0 International License.

Cite as: Brimah, B.A., Bamidele, A.G., Rabiu, R.O., John, I.S. (2020). The Connexus of Management by Objectives and Organisational Performance: Evidence from Tuyil Pharmaceutical Limited, Ilorin. SocioEconomic Challenges, 4(2), 90-98. https://doi.org/10.21272/sec.4(2).90-98.2020.

(C) The Authors, 2020. This article is published with open access at Sumy State University.

\subsection{Introduction}

Employees are been considered to be the backbone of most organization irrespective of its size and structure, organizations around the globe invest on employees because of the pivotal and strategic importance that they play 
in achieving the organization goals (Ojokuku, 2012). Wanting people to perform in high level, high standards of performance should be set. The employees must know precisely why they figure in the payment list, what is expected from them and what makes a high performance (Armstrong, 2009). All organizations, in nowadays, are faced with a competing, unstable and turbulent environment, therefore managers focus is in creating competing advantage through employees' development of organization.

In the presence of the challenges faced by managers in producing a better results in a rapid technological and social change, managers must be able to use this rapid change to produce their results; they must use the change and not be used or swallowed up by it. The most important tool the manager has in setting and achieving forward-looking goals is people, and to achieve results with this tool the manager must: first, be able to instill in the workers a sense of vital commitment and desire to contribute to organizational goals; second, control and coordinate the efforts of the workers toward goal accomplishment; and, last, help his or her subordinates to grow in ability so that they can make greater contributions (Drucker, 1954). In the hopes of increasing individual production and contribution management has resorted to using various techniques and tools to bring out the best performance from their workers (Drucker, 1986).

MBO has been considered as a formal management system with precise review scheduling, set evaluation techniques, and specific formats in which objectives and measures must be presented for review and discussion. In other organizations, it may be so informal as to be described simply as "we get together and decide what we've done and what we're going to do." However, in most organizations, MBO takes the form of formal objective setting and appraisal meetings held on a regular basis often quarterly, semi-annually, or annually (Brim, 2012). This method was generated by the need to ordering actions based on the idea that the success in implementing a development strategy for the unit depends on the correlation of the general objectives with the ones of organizational subdivisions and the interest of the entire personnel of the economic unit (Drucker, 2010).

Regardless of the implementation of this strategy, there are still some factors which serves as a setback on the vision statements, mission statements, purpose and objectives which an organsiation strive to achieve by deploying human, material and financial resources. Some of the identified problems incudes deficiency in planning of organization's policies, programmes and activities usually has a backsliding effect on the operational performance of organizations (Armstrong, 2005). Additionally, lack of control or systems' control in some organization which banking industry is not exempted often affects the overall individual and general performance of organizations in the industry (Armstrong, 2012).

\section{Research Objectives}

The objectives of this study are to;

i. examine relationship between goal commitments and organisation performance.

ii. investigate relationship between performance feedback and organisation performance.

iii. determine relationship between task complexity and organisation performance.

\section{Research Hypothesis}

The following research hypotheses were tested in this research paper;

$\mathbf{H}_{\mathbf{0 1}}$ : Goal commitment does not have any significant relationship with organisational performance.

$\mathbf{H}_{\mathbf{0} 2}$ : Performance feedback does not have any significant relationship with organisational performance.

$\mathbf{H}_{\mathbf{0} 3}$ : Task complexity does not have any significant relationship with organisation performance.

\subsection{Literature review}

\section{a. Conceptual review}

\section{Concept of Management by Objective (MBO)}

Management by objectives is traceable to the period prior to the middle of this century but it was not until 1954 that it was well articulated and publicized by one of the world's leading management thinkers in the person of Peter Ducker. Thus, as a term, "Management by Objectives" was first used by Peter Drucker in 1954. As a management approach, it has been further developed by many management theoreticians, among them Douglas McGregor, George Odiorne, and John Humble. The "Management by Objective" (MBO) approach, in the sense that it requires all managers to set specific objectives to be achieved in the future and 
encourages them to continually ask what more can be done, is offered as a partial answer to this question of organizational vitality and creativity. Management by objectives (MBO) is a process of defining objectives within an organization so that management and employees agree to the objectives and understand what they need to do in the organization (Drucker, 1986).

Essentially, MBO is a process or system designed for supervisory managers in which a manager and his or her subordinate sit down and jointly set specific objectives to be accomplished within a set time frame and for which the subordinate is then held directly responsible. All organizations exist for a purpose, and, to achieve that purpose, top management sets goals and objectives that are common to the whole organization. In organizations that are not using the MBO approach, most planning and objective setting to achieve these common organizational goals is directed downward. Plans and objectives are passed down from one managerial level to another, and subordinates are told what to do and what they will be held responsible for (Atkinson, 2005).

The MBO approach injects an element of dialogue into the process of passing plans and objectives from one organizational level to another. The superior brings specific goals and measures for the subordinate to a meeting with this subordinate, who also brings specific objectives and measures that he or she sees as appropriate or contributing to better accomplishment of the job (Daft, Murphy, \& Willmott, 2010). Together they develop a group of specific goals, measures of achievement, and time frames in which the subordinate commits himself or herself to the accomplishment of those goals.

\section{Requirements for Setting Goals}

Specific and difficult goals influence three key aspects of successful performance (Locke and Latham, 1979):

- direction of attention and effort towards task relevant behaviors and actions;

- investment of effort and energy in goal relevant behaviors;

- Persistence in goal related striving in the face of difficulties or obstacles.

The fundamental requirements of effective and successful goal setting require the following skills and abilities and they are;

\section{Performance Feedback}

Goal setting and performance feedback go hand in hand. Without feedback goal setting is not effective (Latham and Locke, 2006). Thus, in addition to selecting the right goals, managers should also listen to feedback, so that you can gauge how well you and your team are progressing. Feedback provides opportunity to clarify people's expectations and adjust the difficulty of their goals. Keep in mind that feedback doesn't have to come from other people. Performance feedback can be provided on both the outcome and process of goal related striving. Outcome related feedback relates to successful attainment or failure to obtain a desired level of performance. Process related feedback can address effectiveness of performance strategies or plans aimed at achieving a goal, as well as achievement of short term goals that represent incremental progress towards the final goal. Process feedback has been identified as particularly important for complex or difficult tasks. Setting specific and difficult goals for complex tasks may inhibit performance by encouraging a focus on the desired outcome rather than the most effective strategies to reach that point (Locke and Latham, 2013). Providing feedback on the effectiveness of task strategies can overcome this effect.

\section{Goal Setting With Complex Tasks / Work Practices}

Extra care needs to be taken with complex tasks regarding goal setting, commitment and feedback to ensure that the overall effect on performance is beneficial rather than harmful. Task complexity is function of the:

- number of inputs associated with a task, including actions required and information cues to be attended and processed;

- complexity of the coordination required between inputs, for example simultaneous processing of information from a number of different sources and performing difficult physical actions in rapid succession;

- degree and predictability of change in inputs and coordination requirements. 
Take special care to ensure that work doesn't become too overwhelming when goals or assignments are highly complex. People who work in complicated and demanding roles can often push themselves too hard, if they don't take account of the complexity of the task (Locke and Latham, 2002)

\section{Goal Commitment}

Goal commitment is defined as "the degree to which the individual is attached to the goal, considers it significant or important, is determined to reach it, and keeps it in the face of setbacks and obstacles"(Latham and Locke, 1991). It has been suggested that goal commitment interacts with goal difficulty in determining performance. Specifically, with difficult goals, high goal commitment is crucial for high performance. With easy goals, a high level of commitment does not result in high levels of performance since individuals will tend to cease striving once the easy goal is obtained (Klein, Wesson, Hollenbeck, Wright \& Deshon 1997). In general, when averaged across all levels of goal difficulty, goal commitment is positively related to performance (Klein et al, 1997). In the goal setting literature expectancy of goal attainment is commonly operationalised in terms of self efficacy (Klein, Wesson, Hollenbeck, Wright \& Deshon, 2001). To be effective in securing team goal commitment in an organization, employees must understand and agree to the goals employee members are more likely to "buy into" a goal if they have been involved in setting it. Key determinants of goal attainment attractiveness include participation in goal setting, provision of performance feedback, self efficacy, peer pressure/group norms, and rewards/incentives.

\section{b. Theoretical Review}

Goal-setting theory refers to the effects of setting goals on subsequent performance. Researcher Edwin Locke found that individuals who set specific, difficult goals performed better than those who set general, easy goals. In 1990 Edwin Locke and Gary Latham presented a comprehensive theory of goal setting that remains the predominant guiding model for research and practice in organisational psychology. Their theory has been tested on a wide variety of tasks and with a multitude of professions including research scientists, production line workers, nurses, sales representatives, executives, managers and office administrative staff. Goal setting theory is founded on the principle that, with adequate levels of goal commitment and ability, performance increases with increasing goal difficulty (Latham and Locke, 1991).This effect is greater for specific, difficult goals compared to general"do your best" goals (Latham and Locke, 1991).

Goal setting theory is based on the simplest of introspective observations, namely, that conscious human behavior is purposeful. It is regulated by the individual's goals. Goal setting involves the development of an action plan designed to motivate and guide a person or group toward a goal. Goal setting can be guided by goal-setting criteria (or rules) such as SMART criteria. (Locke \& Latham, 1990)

\section{c. Empirical Review}

Ofojebe (2011) did a research on relevance and benefits of management by objectives to secondary school management in Anambra state: teacher's views. The purpose of the of this study was to investigate the statements of secondary school teachers on the relevance and expected benefits of Management by Objectives (MBO) to secondary school management in Anambra State. Guided by two research questions and two null hypotheses, the descriptive survey design was adopted. A sample of 1159 teachers was selected through stratified random sampling technique from secondary schools in the six education zones in Anambra State. The study utilized a 37- item researcher developed questionnaire structured on a 4-point scale. Mean scores were used to answer research questions, while Analysis of variance (ANOVA) was used to test the null hypotheses. The findings of the study indicated that the teachers irrespective of education zones were of the view that all the elements of $\mathrm{MBO}$ are relevant and could be beneficial in achieving continuous improvement in school management. Since the teachers considered MBO to be relevant and beneficial to school management, it was recommended among other things that principals across the six education zones in Anambra State should apply MBO for improved management of their schools.

Thompson, Luthans and Terpening (2015) did a research on The Effects of MBO on Performance and Satisfaction in a Public Sector Organization. This field study examined the effects of MBO on measures of quantity and quality of performance and satisfaction with the work and supervision among employees in a human services agency. Although not all the quantity measures improved significantly, the combined measure for quantity of performance and one of two quality measures showed significant improvement following 
implementation of MBO. Satisfaction with supervision also significantly improved but not satisfaction with work. The study lends support to the use of MBO in public sector organizations.

Nwite Onuma (2016) did a research titled principal's application of management by objective in secondary schools in Ebonyi State, Nigeria The study examined principals' application of management by objective in the administration of schools in Nigeria. Six research questions and two null hypotheses guided the study. The descriptive survey design was adopted for the study. The study sample comprised 204 principals. Data were collected using a questionnaire titled application of Management by Objective schools. Data collected were analyzed using mean $(\mathrm{x})$ and standard deviation while t-test was used to test the hypotheses at 0.05 alpha level. The findings showed that there was no significant difference in the mean ratings between the male and female principals in the application of management by objective in schools. Secondly, there was a significant difference between the mean ratings of urban and rural principals in favor of the urban principals. The study recommended that Secondary Education Board should on regular basis organize seminar workshops for serving principals highlighting the place of MBO in school administration.

King and Flak (2016) did a research whose objective was to present how management by objectives can be used in measuring effectiveness of teams. The main elements of this method - goals and tasks - were used to measure teams'work on the same project. The quantitative measurers of goals and tasks let assess an effectiveness of teams and compare teams to one another. The methodology of the research was an experiment conducted with on-line management tools named goaler and tasker based on the system of organizational terms. This theoretical foundation represent system and positivist approach to management. However, this approach was developed in the mix research method. This paper contains quantitative results and conclusions about effectiveness of teams. For this purpose following measurers were used: numbers of goals and tasks in each group, numbers of actions taken by team managers, duration of teamwork, number of goals and tasks editions. Despite the fact that the method of management by objectives is thoroughly described and parameterized, human contribution in the application of the method in practice appeared still crucial. However, the originality of this paper comes from implementing online management tools which are based on the system of organizational terms and using them to measure human behavior.

Islamia, Mulollia, \& Mustafab (2018) did a research titled Using Management by Objectives as a performance appraisal tool for employee satisfaction. This study deals with the importance of applying Management by Objectives (MBO) method, as a method for performance appraisal (PA) in enhancing employees' effectiveness. A self- administered questionnaire was used, the number of participants included the survey is 172 employees from 13 firms operating in Kosovo. The study aim is to identify the importance of creating objectives, communication objectives, planning goals, setting control points, employees' commitment to determine objectives, freedom and independence in fulfilling duties, continuous communication, as steps for realizing MBO method in employees' effectiveness. The questionnaire of the study was prepared, the responses obtained, the econometric model is constructed in order to test empirically this relationship, passed through the IBM SPSS v.23.0 program has been utilized for the obtained findings. Results and proposals are brought forward by the matched ttest, independent sample t-test, anova, pearson and correlation used as the hypothesis tests. Econometric results suggested that MBO method should be used as a method of performance appraisal as the employees' effectiveness is enhanced. Also it resulted that the evaluation of individual employees' performance and a clear definition of results are the hugest parameters from all the other activities of MBO method which we took in the study to raise employees' effectiveness in organization

\subsection{Methodology}

This study is descriptive in nature as it seeks to describe the usual phenomenon in the field of management while looking at management by objective as a focus. It will also look into the structural design of the study by looking at the design of approaching the targeted respondents. In addition, this study will be quantitative in nature as statistical approach will employed in presenting the report. The population of the study comprises of the entire staff of Tuyil pharmaceutical limited, Ilorin which is Nine hundred and ten (910) respondents, a sample of two hundred and forty-two (242) was drawn out using Guilford and Flusher (1973) formulae. Primary source of data collection was used through a structured questionnaire. A structured questionnaire was used as instrument of data collection. Data was analysed using coding and analysis of quantitative data with descriptive statistics, frequency table and simple percentages while inferential statistics of analysis of variance was used to test the formulated hypothesis in order to achieve the objectives of the research study. 


\subsection{Results and discussion of findings}

\section{Test of Hypothesis I}

$\mathrm{H}_{\mathrm{o} 1}$ : Goal commitment does not have any significant relationship with organisational performance.

Table 1. Analysis of variance showing relationship between goal commitment and organisation performance

\begin{tabular}{|l|c|c|c|c|c|}
\hline \multicolumn{1}{|c|}{ Source } & SS & df & MS & F & Prob $>$ F \\
\hline Between groups & 20.3567901 & 2 & 10.1783951 & 101.02 & 0.0000 \\
\hline Within groups & 8.7654321 & 139 & .100752093 & & \\
\hline Total & 29.1222222 & 241 & .32721598 & & Prob >chi2 $=0.000$ \\
\hline Bartlett's test for equal variances: & \multicolumn{2}{|c|}{ chi2(2)=4.1612 } & \multicolumn{2}{c|}{. } \\
\hline
\end{tabular}

Source: Researcher's analysis (2019) using STATA 11 (statistically significant at 5\%).

The table above shows the relationship between goal commitment and organisation performance using one way ANOVA. Analysis of data showed that the $\mathrm{P}$ value is less than 0.05 , the null hypothesis is rejected while the alternate hypothesis is accepted, and hence there is significant relationship between goal commitment and organisation performance. This implies that the level and degree of goal commitment of employees has significantly improved the performance of the organization. This findings is consistently with the findings of Ofojebe and Olibie (2014), Thompson, Luthans and Terpening (2015), King and Flak (2016) and Islamia, Mulollia, \& Mustafab (2018) who concluded in their studies that there is significant relationship between goal commitment and organisation performance.

\section{Test of Hypothesis II}

$\mathbf{H}_{\mathbf{0} 2}$ : Performance feedback does not have any significant relationship with organisational performance.

Table 2. Analysis of variance showing relationship between performance feedback and organisation performance

\begin{tabular}{|l|c|c|c|c|c|}
\hline \multicolumn{1}{|c|}{ Source } & SS & df & MS & F & Prob > F \\
\hline Between groups & 19.0045752 & 1 & 9.50228758 & 200.77 & 0.0000 \\
\hline Within groups & 4.11764706 & 240 & .047329277 & & \\
\hline Total & 23.1222222 & 240 & .25980025 & & \\
\hline \multicolumn{2}{|c|}{ chi2(2) $=7.1210$} & \multicolumn{2}{c|}{ Prob $>$ chi $2=0.000$} \\
\hline
\end{tabular}

Source: Researcher's analysis (2019) using STATA 11 (statistically significant at 5\%).

The table above shows the relationship between performance feedback and organisation performance using one way ANOVA. Analysis of data showed that the P value is less than 0.05 , the null hypothesis is rejected while the alternate hypothesis is accepted, and hence there is significant relationship between performance feedback and organisation performance. This implies that the level and degree of performance feedback of employees has significantly improved the performance of the organization. This findings is consistently with the findings of Ofojebe and Olibie (2015), Thompson, Luthans and Terpening (2015), King and Flak (2016), Krueger (2016), and Islamia, Mulollia, \& Mustafab (2018) who concluded in their studies that there is significant relationship between performance feedback and organisation performance.

\section{Test of Hypothesis III}

$\mathbf{H}_{\mathbf{0 1}}$ : Task complexity does not have any significant relationship with organisation performance.

Table 3. Analysis of variance showing relationship between task complexity and organisation performance

\begin{tabular}{|l|c|c|c|c|c|}
\hline \multicolumn{1}{|c|}{ Source } & SS & df & MS & F & Prob $>$ F \\
\hline Between groups & 2.78181818 & 1 & 2.78181818 & 46.03 & 0.0000 \\
\hline Within groups & 5.31818182 & 240 & .060433884 & & \\
\hline Total & 8.1 & 241 & .091011236 & & Prob >chi2 $=0.000$ \\
\hline Bartlett's test for equal variances: & chi2(2)=3.5331 & \\
\hline
\end{tabular}

Source: Researcher's analysis (2019) using STATA 11 (statistically significant at 5\%).

The table above shows the relationship between task complexity and organisation performance using one way ANOVA. Analysis of data showed that the $\mathrm{P}$ value is less than 0.05 , the null hypothesis is rejected while the alternate hypothesis is accepted, and hence there is significant relationship between task complexity and organisation performance. This implies that the level and degree of task complexity has significantly improved the performance of the organization. This findings is consistently with the findings of Ofojebe and Olibie 
(2015), Thompson, Luthans and Terpening (2015), King and Flak (2016), Krueger (2016), and Islamia, Mulollia, \& Mustafab (2018) who concluded in their studies that there is significant relationship between task complexity and organisation performance.

\subsection{Conclusion}

Vision, mission and objectives are tripods that organisations all around the globe pay maximum attention to because of the relationship it has with the continuous existence of the organisation. profitability, productivity, market share, maximisation of shareholders equity, growth and survival, market share, employee welfare etc are objectives that organisations strives to achieve regardless of its type, nature or size. Management by objectives in its ideal form operates in such a way that for the corporate goals to be realized, manager should consult his subordinates in drawing up unit objectives, which goes up the hierarchy from where it is modified, collected, approved and distributed throughout the organization. Thus, the totality of employee efforts must all pull in the same direction and their contribution must fit together to produce a whole without friction and without duplication of effort. This is the philosophy behind management by objectives. Based on the findings of this study, it can be concluded that that there is significant relationship between goal commitments and organization performance; there is significant relationship between performance feedback and organization performance; there is significant relationship between task complexity and organization performance

\subsection{Recommendations}

Based on the findings of the study, the following recommendations are proposed

Organisation must ensure that they continually engage in best practices that will ensure that employees are committed to the organisational goals. Thus, employees must be attracted to organisational goals and the one of the key determinants of goal attainment attractiveness is participation in goal setting which organization must emphasize on.

Organisation must continually ensure that performance feedback is enshrined in its corporate strategy and organization culture since without feedback, goal setting is not effective. This is also in furtherance of the fact that feedback provides opportunity to clarify expectations and adjust where necessary. Thus, performance feedback of organisation must be one that emphasises on outcome related feedback which relates to successful attainment or failure to obtain a desired level of performance as well as process related feedback which has capacity to address effectiveness of performance.

Organisation must continually be abreast of environmental changes to find out more information on emerging trends associated with a task, including actions required and information cues to be attended and processed, complexity of the coordination required between inputs and degree and predictability of change in inputs and coordination requirements. This will ensure that complexity associated with performing a task in terms of inadequate information is addressed to a large extent.

\section{References}

1. Armstrong, M. (2009). Armstrong's Handbook of Human Resource Management Practice. New York, NY: $\quad$ Kogan Page Publishers. https://www.academia.edu/32280546/ARMSTRONGS_HANDBOOK_OF_HUMAN_RESOURCE_M ANAGEMENT_PRACTICE_i.

2. Armstrong, M. and Baron, A. (2005). Managing performance: performance management in action. New York McGraw Hill Book Co. https://www.amazon.co.uk/Managing-Performance-ManagementDeveloping-Practice/dp/1843981017.

3. Armstrong, M. (2012). Armstrong's Handbook of Human Resource Management Practice. New York, NY: Kogan Page Publishers. https://euczelnia.uek.krakow.pl/pluginfile.php/604792/mod_folder/content/0/Armstrongs\%20Handbook\%20of $\% 20$ Human\%20Resource\%20Management\%20Practice_1.pdf?forcedownload=1.

4. Atkinson, W. (2005). Setting goals and measuring performance. Collections \& Credit Risk, 10(8), $32-34$. chromeextension://ohfgljdgelakfkefopgklcohadegdpjf/http://jbepnet.com/journals/Vol 3 No_1_March_2016/8.pdf. 
5. Brim, R. (2012). A history of MBO and recommendations for today's managers: Helping people be productive. From MBO to DEMING to project management and beyond. White paper prepared on performance solutions technology, LLC. https://EconPapers.repec.org/RePEc:eco:journ.

6. Daft, R. L., Murphy, J., \& Willmott, H. (2010). Organization theory and design. Cengage learning EMEA. Available at: https://www.researchgate.net/publication/310455811.

7. Drucker, P., E. (1954). The Practice of Management, New York, 1954. https://www.worldcat.org/title/practice-of-management/oclc/230717.

8. Drucker, P., F. (1986). The Frontiers of Management, Truman Talley Books, New York. https://trove.nla.gov.au/work/8737984.

9. Guilford and Flusher (1973). Fundamental statistics in psychology education. McGrawill, New York. Pp. 100-105. https://onlinelibrary.wiley.com/doi/abs/10.1002/sce.3730410357.

10. Islamia, X, Mulollia,E, Mustafa,N (2018). Using Management by Objectives as a performance appraisal tool for employee satisfaction. Future Business Journal. 4(1), 94-108. https://www.academia.edu/36013700/Using_Management_by_Objectives_as_a_performance_appraisal tool_for_employee_satisfaction.

11. Klein, H. J., Wesson, J. M., Hollenbeck, J.K., Wright, P.M., \& DeShon, R.P. (2001). The assessment of goal commitment: A measurement model meta-analysis. Organizational Behavior and human Decision Process, 85 (1), 32-55. https://www.ncbi.nlm.nih.gov/pubmed/11341816.

12. Klein, H. J., Wesson J. M., Hollenbeck J. R., \& Alge, B. J. (1997). Goal commitment and the Goal-setting Process: Conceptual Clarification and Empirical Synthesis. Journal of Applied Psychology, 84 (6), $885-$ 896. https://psycnet.apa.org/record/1999-15531-005.

13. Kinga, O. \& Flak, O. (2016). Management by objectives as a method of measuring teams' effectiveness. Journal of positive management, 6(3), 67-82. https://www.researchgate.net/publication/301597505_MANAGEMENT_BY_OBJECTIVES_AS_A_M ETHOD_OF_MEASURING_TEAMS'_EFFECTIVENESS.

14. Latham, G. P., \& Locke, E. A. (1979). Goal setting-A motivational technique that works. Organizational Dynamics, $8(2)$, 68-80. https://www.academia.edu/26293644/Goal setting A motivational technique that works.

15. Latham, G.P (2004). The motivational benefits of goal-setting. The Academy of Management Executive, 18(4), 126-145. https://pdfs.semanticscholar.org/496c/f6e7b4a42945deb49f54a7ce271cbca1562e.pdf.

16. Locke, E. A. \& Latham, G. P. (1991). Goal theory vs. control theory: Contrasting approaches to understanding work motivation. Motivation and Emotion, 15 (1), 9-28. https://books.google.com.ua/books?id=hGANRIXbkp0C\&pg=PA466\&lpg=PA466\&dq=16.\%09Locke, +E.+A.+\%26+Latham, + G. + P.+(1991).+Goal+theory+vs.+control+theory:+Contrasting+approaches+to +understanding+work+motivation.+Motivation+and+Emotion $,+15+(1),+9 \% \mathrm{E} 2 \% 80 \% 9328 . \&$ source $=\mathrm{bl}$ $\underline{\text { \&ots }=\mathrm{yFW}-}$

J9Ctib\&sig=ACfU3U0aQfFTHviqWv6LAQi599JonURZ4Q\&hl=uk\&sa=X\&ved=2ahUKEwiou7CKzP LpAhWK6KYKHZ6YCJ0Q6AEwAHoECAgQAQ.

17. Locke, E.A \& Latham, G.P. (2013). New developments in goal setting and task performance, Wals worth Publishing Company, USA. https://www.amazon.com/Developments-Goal-Setting-TaskPerformance/dp/0415885485.

18. Locke, E. A., \& Latham, G. P. (2002). Building a practically useful theory of goal setting and task motivation: A 35-year Odyssey. American Psychologist, 57 (9), 705-717. http://psycnet.apa.org/journals/amp/57/9/705/.

19. Locke, E. A. \& Latham, G. P. (2006). New directions in goal-setting theory. Current Directions in $\begin{array}{llllr}\text { Psychological } & \text { Science, } & 15 & \text { 265-268. }\end{array}$ https://home.ubalt.edu/tmitch/642/Articles\%20syllabus/locke\%20latham\%20new\%20dir\%20GS\%20cur r\%20dir\%20psy\%20sci\%202006.pdf

20. Ofojebe, W. (2011). Relevance and benefits of management by objectives to secondary school management in Anambra State:Teachers views. International Journal of Educational Administration and Policy Studies, 2(7), 99-104. https://www.academia.edu/11161653/Relevance_and_benefits_of_management_by_objectives_to_seco ndary_school_management_in_Anambra_State_Teachers_views.

21. Ofojebe, W.N. \& Olibie, E.I. (2014). Management by Objectives (MBO) Imperatives for Transforming Higher Education for a Globalised World. Journal of International Education and Leadership, 4 (2), 1- 
10.

chrome-

extension://ohfgljdgelakfkefopgklcohadegdpjf/https://files.eric.ed.gov/fulltext/EJ1135899.pdf.

22. Ojokuku, R.M. (2012). Human Resource Management Demands and Challenges in Small and Medium Scale Enterprises, International Journal of Economic Development Research and Investment. 3(3), 1-10. https://www.icidr.org/ijedri vol3 no3 dec2012/Human\%20Resources\%20Management\%20Demands\% 20 and $\% 20$ Challenges $\% 20$ in $\% 20$ Small $\% 20$ and $\% 20$ Medium\%20Scale\%20Enterprises.pdf

23. Rodgers, R. \& Hunter, J. E. (1991). Impact of management by objectives on organizational productivity. Journal of Applied Psychology, 76(2), 322. https://psycnet.apa.org/record/1991-25999-001

24. Thompson, K.R., Luthans, F., and Terpening, Willbann, D. (2015). The Effects of MBO on Performance and Satisfaction in a Public Sector Organization (1981). Leadership Institute Faculty Publications. Journal of Management 53-68. http://digitalcommons.unl.edu/cgi/viewcontent.cgi?article=1021\&context=leadershipfacpub

25. Wu, B. (2005). The philosophy and practice of Management by Objectives. Alabama, United States: Troy State University.

http:/libroweb.alfaomega.com.mx/book/385/free/data/Materiales/Capitulo05/ThePhilosophyandPractice.pdf. 